\title{
Pengaruh Pemberian Jus Daun Bayam Hijau Terhadap Peningkatan Kadar Hemoglobin Pada Ibu Hamil Dengan Anemia Di Wilayah Puskesmas \\ Sangatta Selatan
}

Sumiati ${ }^{1}$, Indah Sulistiyo Rini ${ }^{2}$, Tuti Meihartati ${ }^{3}$

1,2,3Program Studi S-1 Kebidanan, Institut Teknologi \& Sains Wiyata Husada Samarinda

Email: sumiati@itkeswhs.ac.id, indahsulistyorini69@gmail.com, tuti@itkeswhs.ac.id

\begin{abstract}
Abstrak
Ibu hamil akan memproduksi sel darah lebih banyak untuk menyokong pertumbuhan janin. Bila tubuh tidak cukup memiliki jumlah zat besi atau vitamin lain, tubuh tidak dapat memproduksi sel darah merah yang dibutuhkan untuk menambah kebutuhan sel darah sehingga anemia terjadi. Pemberian jus bayam hijau, yang kaya akan zat besi, merupakan salah satu alternatif terapi non farmakologi untuk mencegah terjadinya anemia. Mengetahui pengaruh pemberian jus daun bayam hijau terhadap kenaikan kadar hemoglobin pada ibu hamil dengan anemia di wilayah Puskesmas Sangatta Selatan. One Group Pre Test-Post Test Design dengan sampel 24 orang yang dipilih menggunakan teknik purposive sampling. Uji normalitas data menggunakan uji Shapiro-Wilk dan uji hepotesis menggunakan uji Wilcoxon. Ada pengaruh pemberian jus bayam hijau terhadap peningkatan kadar hemoglobin pada ibu hamil dengan anemia dengan p-vlaue $=0,000$. Pemberian jus daun bayam hijau merupakan salah satu upaya yang efektif untuk menaikkan kadar hemoglobin pada ibu hamil dengan anemia.
\end{abstract}

Kata Kunci: Ibu hamil anemia, jus bayam hijau, kadar hemoglobin

\begin{abstract}
Background: Pregnant women will produce more blood cells to support fetal growth. If the body does not have enough iron or other vitamins, the body cannot produce red blood cells needed to increase the need for blood cells so that anemia occurs. Giving green spinach juice, which is rich in iron, is one of the alternative non-pharmacological therapies to prevent anemia. Objective: Knowing the effect of giving green spinach leaf juice on the increase in hemoglobin levels in pregnant women with anemia in the South Puskesmas area. Method: One Group Pre Test-Post Test Design with a sample of 24 people chosen using purposive sampling techniques. The data normality test uses the Shapiro-Wilk test and hepotesis test using the Wilcoxon test. Result: There is an effect of giving green spinach juice on increasing hemoglobin levels in pregnant women with anemia with $p$-vlaue $=0,000$. Conclusion: Green Spinach Leaf Juice is one of the effective efforts to increase hemoglobin levels in pregnant women with anemia.
\end{abstract}

Keywords: Anemic pregnant women, green spinach juice, hemoglobin levels 


\section{PENDAHULUAN}

Selama kehamilan banyak faktor resiko yang dapat menyebabkan terjadinya komplikasi pada ibu hamil antara lain terjadinya anemia pada ibu hamil, perdarahan, berat badan abnormal dan terkena penyakit infeksi (Depkes RI, 2012). Salah satu yang harus diwaspadai pada saat kehamilan adalah anemia pada kehamilan. Anemia pada ibu hamil adalah kondisi dimana kadar hemoglobin di bawah $11 \mathrm{gr} / \mathrm{dl}$. Penyebab utamanya adalah kurangnya asupan zat besi (Manuaba, 2010).

Secara global prevalensi anemia pada ibu hamil di seluruh dunia adalah sebesar $41,8 \%$. Prevalensi anemia pada ibu hamil diperkirakan di Asia sebesar 48,2\%, Afrika 57,1\%, Amerika 24,1\%,dan Eropa 25,1\% (WHO, 2011). Angka kejadian anemia kehamilan di Indonesia menunjukkan nilai yang cukup tinggi yaitu untuk ibu hamil dengan umur $15-24$ tahun $84,6 \%$, pada umur 25-34 tahun 33,7\%, pada umur 35-44 tahun $33,6 \%$ dan umur $45-54$ tahun $24 \%$ (Riskesdas, 2018). Dari studi pendahuluan yang dilakukan di Puskesmas wilayah Sangatta Selatan, pada tahun 2019 terdapat 370 ibu hamil yang diperiksa kadar hemoglobinnya terdapat 86 orang $(23,2 \%)$ ibu hamil dengan anemia. Ibu dengan anemia ringan sampai sedang ( $\mathrm{Hb} \quad 8-11 \quad \mathrm{gr} / \mathrm{dl})$ sebanyak 76 orang $(20,5 \%)$ dan ibu dengan anemia berat $(\mathrm{Hb}<8 \mathrm{gr} / \mathrm{dl})$ sebanyak 10 orang $(2,7 \%)$ (Data sekunder puskesmas sangatta selatan, 2019).

Penanganan anemia pada ibu hamil biasanya dilakukan dengan 2 cara, yaitu: secara farmakologis dan non farmakologis. Upaya farmakologis dilakukan oleh pemerintah dengan cara pemberian $60 \mathrm{mg}$ tablet Fe dan 50 nanogram asam folat selama kehamilan (Kemenkes, 2017). Ibu hamil harus mengkonsumsi tablet $\mathrm{Fe}$ minimal 1 tablet setiap hari hingga 90 tablet. Konsumsi tablet $\mathrm{Fe}$ ini ternyata menimbulkan beberapa efek samping pada ibu hamil seperti mual, muntah, konstipasi dan nyeri hulu hati (Sivanganam, 2015). Hal inilah yang menyebabkan tingkat kepatuhan ibu hamil mengkonsumsi tablet $\mathrm{Fe}$ tergolong rendah. Adapun upaya non farmakologis salah satu diantaranya adalah mengkonsumsi buah-buahan dan sayuran yang banyak mengandung zat besi dan vitamin C. Bayam merupakan salah satu bahan makan sayuran yang paling tinggi mengandung zat besi yaitu $3,9 \mathrm{mg} / 100$ gram dari pada bahan jenis sayuran yang lainnya, seperti sawi 2,9 mg, daun katuk 2,7 mg, kangkung 2,5 mg, daun singkong 2,0 mg (Merlina, 2016).

Berdasarkan latar belakang diatas inilah peneliti tertarik mengambil bahasan penelitian tentang upaya non farmakologis sebagai upaya alternatif pemenuhan kebutuhan zat besi untuk meningkatkan kadar hemoglobin pada ibu hamil dengan anemia dalam hal ini dengan pemberian jus bayam. Bayam sendiri dipilih oleh penulis karena dianggap sebagai salah satu bahan makan sayuran yang murah, tersedia di banyak tempat, dan mengandung zat besi yang tinggi. 


\section{METODE PENELITIAN}

Penelitian ini menggunakan One Group Pre Test-Post Test Design, yaitu melakukan satu kali pengukuran kadar $\mathrm{Hb}$ pada responden di depan (pretest) sebelum adanya intervensi (treatment) pemberian jus bayam selama 7 hari dan setelah itu dilakukan pengukuran kadar $\mathrm{Hb}$ lagi (posttest) setelah intervensi.

Sampel pada penelitian ini sejumlah 24 responden diambil dari populasi 43 ibu hamil yang berkunjung ke Puskesmas Sangatta Selatan yang melakukan pemeriksaan kadar hemoglobin $(\mathrm{Hb})$ dari bulan Oktober - Desember 2020 dengan menggunakan teknik non probability sampling dengan pendekatan purposive sampling yaitu pengambilan sampel yang didasarkan atas pertimbangan dan sesuai dengan kriteria yang dikehendaki peneliti yang meliputi kriteria inklusi dan eksklusi (Nursalam, 2013).

Instrumen dalam penelitian ini antara lain adalah EasyTouch ( $\mathrm{GcHb})$ beserta SOP untuk pengukuran kadar $\mathrm{Hb}$ responden, SOP pembuatan jus bayam untuk standarisasi dan lembar checklist penelitian yang berisi jadwal dan checklist pemberian jus bayam agar penelitian sesuai dengan yang direncanakan.

Analisa univariat dilakukan untuk melihat gambaran distribusi frekuensi dari setiap variabel yang diteliti. Analisa bivariat yang akan dilakukan adalah untuk mengetahui pengaruh pemberian jus bayam hijau terhadap peningkatan kadar hemoglobin ibu hamil dengan anemia. Uji yang dilakukan dalam analisa ini adalah uji normalitas data Shapiro-Wilk dan uji hipotesa menggunakan uji paired $t$ test (jika data berdistribusi normal) atau uji wilcoxon (jika data tidak berdistribusi normal).

\section{HASIL}

Dari 24 sampel yang diambil sebagai responden diperoleh data karakteristik responden sesuai dengan tabel berikut.

Tabel 1 Karakteristik Responden

\begin{tabular}{lcc}
\hline Karakteristik & Frekuensi & $\%$ \\
\hline Usia & & \\
$\quad<20$ tahun & 1 & 4,16 \\
$20-35$ tahun & 16 & 66,67 \\
$\quad 35$ tahun & 7 & 29,17 \\
\hline $\begin{array}{l}\text { Paritas } \\
\text { Primipara }\end{array}$ & 3 & 12,50 \\
$\quad$ Multipara & 21 & 87,50 \\
\hline Pendidikan & & \\
$\quad$ SD & 1 & 4,16 \\
SD & 3 & 12,50 \\
SMP & 6 & 25,00 \\
SMU & 10 & 41,67 \\
Perguruan & 4 & 16,67 \\
Tinggi & & \\
\hline Pekerjaan & 6 & 25,00 \\
Bekerja & 18 & 75,00 \\
$\quad$ Tidak Bekerja & 18
\end{tabular}

Sumber: Data Primer Hasil Penelitian 2020

Karakteristik usia sebagian besar responden (66,67\%) adalah antara 20 - 34 tahun. Paritas hampir seluruh responden $(87,5 \%)$ adalah ibu hamil multipara. Hampir setengah responden $(41,67 \%)$ memiliki tingkat pendidikan SMU. Sebagian besar responden (75\%) merupakan ibu hamil yang tidak bekerja atau hanya sebagai ibu rumah tangga.

Tabel 2 Distribusi Frekuensi Kadar $\mathrm{Hb}$ Sebelum dan Sesudah Pemberian Jus Bayam

\begin{tabular}{|c|c|c|c|c|c|}
\hline \multirow{2}{*}{\multicolumn{2}{|c|}{ Kadar Hb (gr/dl) }} & \multicolumn{2}{|c|}{ Sebelum } & \multicolumn{2}{|c|}{ Sesudah } \\
\hline & & $f$ & $\%$ & $f$ & $\%$ \\
\hline 11 & Tidak Anemia & 0 & 0,00 & 1 & 45,8 \\
\hline $9-10$ & Anemia & & 62,5 & 1 & 3 \\
\hline Ringan & & 5 & 0 & 1 & 54,1 \\
\hline $7-8:$ & Anemia & 9 & 37,5 & 3 & 7 \\
\hline Sedang & & 0 & 0 & 0 & 0,00 \\
\hline$<7$ & Anemia Berat & & 0,00 & 0 & 0,00 \\
\hline
\end{tabular}

Sumber: Data Primer Hasil Penelitian 2020

Sebelum dilakukan intervensi pemberian jus bayam pada responden yaitu 
ibu hamil dengan anemia, sebagian besar responden (62,50\%) mengalami anemia ringan dan hampir setengahnya (37,50\%) mengalami anemia sedang. Sesudah dilakukan intervensi pemberian jus bayam, hampir setengah responden (45,83\%) telah sembuh dari anemia dan sebagian besar responden $(54,17 \%)$ sisanya masih mengalami anemia ringan.

Tabel 3 Pengaruh Pemberian Jus Bayam Hijau terhadap Peningkatan Kadar Hemoglobin pada Ibu Hamil dengan Anemia dengan Uji Wilcoxon

sesudah pemberian jus bayam - sebelum pemberian jus bayam

\begin{tabular}{llr}
\hline$Z$ & & -4.244 \\
Asymp. & Sig. $\quad(2-$ & .000 \\
tailed) & & \\
\hline
\end{tabular}

Sumber: Data Primer Hasil Penelitian 2020

Karena nilai Sig. atau $p$ value $<\alpha$ yaitu $0,000<0,05$ sesuai pengujian statistik dapat disimpulkan bahwa terdapat pengaruh antara pemberian jus bayam dengan peningkatan kadar hemoglobin pada ibu hamil dengan anemia.

\section{PEMBAHASAN}

Sebelum pemberian jus bayam, sebagian besar responden (62,50\%) mengalami anemia ringan dan hampir setengahnya $(37,50 \%)$ sisanya mengalami anemia sedang. Adapun rata-rata kadar hemoglobin responden sebelum pemberian jus bayam adalah $9,90 \mathrm{gr} / \mathrm{dL}$ dan dapat digolongkan ke dalam anemia ringan karena berada antara $9-10 \mathrm{gr} / \mathrm{dl}$.

Setelah pemberian jus bayam, hampir setengah responden (45,83\%) tidak anemia lagi dan sebagian besar responden (54,17\%) mengalami anemia ringan. Tidak ada responden $(0 \%)$ yang mengalami anemia sedang dan berat. Rata-rata kadar hemoglobin setelah intervensi mengalami peningkatan yakni 10,31 gr/dL.

Rata-rata kadar hemoglobin $(\mathrm{Hb})$ setelah pemberian jus bayam yaitu 10,31 . Hal ini menunjukkan bahwa pemberian jus bayam selama tujuh hari dapat meningkatkan kadar hemoglobin pada ibu hamil. Hal ini sesuai dengan Elsabrina (2018) yang mengatakan bahwa zat besi yang terdapat pada daun bayam sangat tinggi dibandingkan sayuran daun lain. Fungsi utamanya adalah mentransformasikan ketika mendistribusikan oksigen ke seluruh tubuh.

Adapun manfaat zat besi ini adalah sebagai penyusun sitrokom, dan protein yang terlibat dalam proses fotosintesis dengan begitu berguna untuk penderita anemia. Selain itu, bayam juga mengandung antioksidan esensial dan fitokimia yang membantu melindungi tubuh terhadap berbagai penyakit. Menurut Qolik (2014) Bayam merupakan sumber zat besi yang baik. Zat besi diperlukan untuk mencegah anemia atau kekurangan sel darah merah. Zat besi bermanfaat untuk memperbanyak (meregenerasi) sel darah yang membawa oksigen ke seluruh tubuh sehingga dapat mencegah terkena anemia.

Anemia merupakan jenis penyakit yang disebabkan oleh kurangnya hemoglobin atau butir darah merah pada tubuh. Darah normal terdiri $40-45 \%$ butir darah merah dan sekitar 55-60\% plasma darah. Setiap 100 mililiter darah biasanya terdapat 4.500 .000 sampai 5.500.000 sel darah merah, jika darah seseorang kurang dari jumlah darah yang 
terendah maka tergolong anemia (Maria 2008 dalam Sari at.al 2019)

Menurut Supariasa, et al, 2012 dalam Jaya at al 2020) hemoglobin merupakan parameter yang digunakan untuk menetapkan prevalensi anemia. Hemoglobin merupakan senyawa pembawa oksigen pada sel darah merah. Hemoglobin dapat diukur secara kimia dan jumlah $\mathrm{Hb} / 100 \mathrm{ml}$ darah dapat digunakan sebagai indek kapasitas pembawa oksigen pada darah. Konsentrasi hemoglobin normal pada wanita hamil berbeda dengan wanita yang tidak hamil, hal ini disebabkan karena pada masa kehamilan terjadi proses hemodilusi atau pengenceran darah, yaitu peningkatan volume plasma dalam proporsi yang lebih besar di banding dengan peningkatan eritrosit. Hemdilusi ini berfungsi agar suplai darah untuk pembesaran uterus terpenuhi, melindungi ibu dan janin dari kehilangan darah saat proses persalinan (Manuaba, 2010 dalam Jaya at al 2020).

Kekurangan zat besi bisa menimbulkan gangguan atau hambatan pada pertumbuhan janin baik sel tubuh maupun sel otak, selain itu dapat juga mengakibatkan cacat bawaan, abotus, BBLR, anemia pada bayi yang dilahirkan dan kematian janin dalam kandungan (Sukarni dan Margareth, 2013 dalam Sari at al 2019).

Hasil penelitian yang dilakukan oleh Wijayanti, T. (2016) di desa Pendem kecamatan Junrejo menunjukkan bahwa dengan mengkonsumsi jus bayam selama 10 hari dapat meningkatkan kadar hemoglobin (Hb) dalam darah ibu hamil trimester pertama yang mengalami anemia sampai kembali normal. Hasil ini juga sejalan dengan penelitian yang dilakukan oleh Kundaryanti, at al (2018) di wilayah kerja Puskesmas Pasar Minggu Jakarta Selatan yang menunjukkan bahwa ada pengaruh pemberian jus bayam hijau terhadap perubahan kadar hemoglobin ibu hamil anemia.

Menurut pandangan peneliti, pemberian jus bayam yang diberikan sesuai dengan SOP yaitu dengan cara daun bayam hijau sebanyak $50 \mathrm{gr}$ diblender dengan air masak sebanyak 150ml hingga diperoleh jus bayam sebanyak $200 \mathrm{ml}$ ( \pm 1 gelas) yang diberikan sebelum makan pagi selama 7 hari, efektif untuk meningkatkan kadar hemoglobin bagi ibu hamil.

Hasil uji Wilcoxon bahwa nilai $p$-value atau nilai sig. 0,000. Nilai ini jauh lebih kecil dari nilai $\alpha$ yang di tentukan dalam penelitian ini yakni 0,05 . Karena nilai $p$-value $<\alpha$ maka dapat disimpulkan bahwa $\mathrm{Ho}$ ditolak dan $\mathrm{Ha}$ diterima. Ini membuktikan bahwa pemberian terapi jus bayam mempunyai pengaruh terhadap peningkatan kadar hemoglobin ibu hamil dengan anemia.

Setiap $100 \mathrm{gr}$ bayam terkandung 2,3 gr protein, 3,2 $\mathrm{gr}$ karbohidrat, $3 \mathrm{gr}$ besi juga $81 \mathrm{gr}$ kalsium. Bayam sangat kaya dengan berbagai macam vitamin dan juga mineral yaitu vitamin $A$, vitamin $C$, niasin, thiamine, fosfor, natrium, ribolvin, kalium dan magnesium (Yunaifi, S., 2013). Bayam merupakan sayuran yang memiliki gizi lengkap untuk penderita anemia. Bayam juga mengandung vitamin $\mathrm{C}$ yang juga memiliki peranan penting dalam penyerapan zat besi sehingga zat besi dapat dimanfaatkan secara optimal (Lingga, L., 2010)

Daun bayam hijau (Amarantus hybridus L) memiliki kandungan zat besi (Fe) 
sebesar $6,43 \%$ mg per 180 gr. Fungsi dari zat besi adalah untuk membentuk sel darah merah. Jika sel darah merah dalam tubuh cukup maka kadar hemoglobin akan normal (Arisman, 2007). Mineral dalam zat besi sangat dibutuhkan dalam hemopoiesis, namun zat besi sangat sulit diserap oleh tubuh. Pada proses pencernaan, besi mengalami proses reduksi dari bentuk feri (Fe3+) ke fero (Fe2+) agar mudah diserap (Winarno, F.G., 2004).

Menurut Linder 2010 absorbsi besi yang efisien dan efektifadalah dalam bentuk fero karena mudah larut. Untuk itu diperlukan suasana asam didalam lambung dan senyawa yang dapat mengubah Feri menjadi Fero di dalam usus, senyawa yang dimaksud adalah asam askorbat (vitamin C) kedua senyawa besi $(\mathrm{Fe})$ dan vitamin $\mathrm{C}$ tersebut dimiliki oleh bayam ( A.tricolor L). Selain itu kecepatan absorbsi besi juga dipengaruhi oleh kadar besi bplasma (Ganong, 2009 dalam Wijayanti 2019)

Hasil penelitian yang dilakukan oleh Wijayanti, T. (2016) di desa Pendem kecamatan Junrejo yang berjudul "Perbaikan Status Hb Pada Ibu Hamil Trimester Pertama Dengan Jus Daun Bayam" dengan nilai $p$ value $<0,05$ hal ini menunjukkan bahwa daun bayam efektif meningkatkan kadar $\mathrm{Hb}$ pada ibu hamil trimester pertama.

Menurut peneliti adanya peningkatan rata-rata kadar hemoglobin setelah pemberian jus bayam hijau selama 7 hari, hal ini dikarenakan bayam banyak mengandung zat besi yang merupakan mineral yang sangat dibutuhkan dalam proses hematopoiesis. Vitamin $\mathrm{C}$ yang terkandung dalam bayam dapat membantu penyerapan besi dengan cara mereduksi feri menjadi fero yang mudah diserap 3-6 kali.

Selain itu salah satu faktor yang mempengaruhi peningkatan kadar hemoglobin pada penelitian ini adalah adanya komponen yang mempengaruhi absorbsi zat besi yakni asamaskorbat (vitamin C) sebesar $80 \mathrm{mg} / 100 \mathrm{gr}$, selain itu bayam juga mengandung zat besi yang cukup tinggi yaitu 3,9mg/100gr (Bandini, 2004 dalam Wijayanti 2016).

\section{Kesimpulan}

Berdasarkan hasil penelitian didapatkan kesimpulan sebagai berikut:

1. Sebelum intervensi pemberian jus bayam, sebagian besar (62,5\%) mengalami anemia ringan dan hampir setengahnya $(37,5 \%)$ mengalami anemia sedang dengan skor rata-rata kadar $\mathrm{Hb} 9,90 \mathrm{gr} / \mathrm{dl}$.

2. Setelah pemberian jus bayam, hampir setengahnya $(45,83 \%)$ sembuh dari anemia dan sebagian besar sisanya $(54,17 \%)$ mengalami anemia ringan dengan skor rata-rata kadar $\mathrm{Hb}$ 10,31 gr/dl.

3. Dari hasil penelitian menunjukkan bahwa ada pengaruh sebelum dan setelah pemberian jus bayam terhadap peningkatan kadar $\mathrm{Hb}$ ibu hamil dengan anemia di Puskesmas Sangatta Selatan dengan nilai siginifikansi (Asymp. Sig.) atau $p$-value $=0,000$.

\section{Ucapan Terima Kasih}

Dalam menyelesaikan penelitian ini, peneliti mengucapkan terima kasih kepada: 
1. Bapak H Mujito Hadi, M.M. selaku Ketua Yayasan ITKES Wiyata Husada Samarinda.

2. Bapak Dr. Eka Ananta Sidharta, S.E., M.M., Ak., CA., CFrA. selaku Rektor ITKES Wiyata Husada Samarinda.

3. Ibu Hestri Norhapifah, SST., M.Keb. selaku Ketua Program Studi Kebidanan ITKES Wiyata Husada Samarinda.

4. Ibu Tuti Meihartati, SST., M.Kes. selaku dosen pembimbing I yang telah menyediakan waktu, tenaga dan pikiran untuk mengarahkan saya dalam penyusunan skripsi ini.

5. Ibu Eka Frenty Hadiningsih, SST., M.Keb. selaku dosen pembimbing II yang telah menyediakan waktu, tenaga dan pikiran untuk mengarahkan saya dalam penyusunan skripsi ini.

6. UPT Puskesmas Sangatta Selatan yang telah banyak membantu dalam usaha memperoleh data yang saya perlukan.

7. Orang tua dan yang telah memberikan izin, doa, serta dukungan kepada saya.

8. Suami dan anak-anak tercinta yang telah memberikan dukungan dan semangat selama menjalani kuliah.

9. Seluruh teman dan sahabat yang telah memberikan dukungan dalam proses perkuliahan dan pelaksanaan penelitian.

\section{Referensi}

Arisman (2007) Gizi dalam Daur Kehidupan. Jakarta: EGC

Kemenkes RI (2018) Hasil Utama Riskesdas 2018. Jakarta: Badan Penelitian dan Pengembangan Kesehatan Kementerian Kesehatan Republik Indonesia
Kundaryanti et al. (2019) Pengaruh Pemberian Jus Bayam Hijau terhadap Peningkatan Kadar Hemoglobin pada lbu Hamil Anemia di Wilayah Kerja Puskesmas Pasar Minggu Jakarta Selatan Tahun 2018. Jurnal IImu Keperawatan dan Kebidanan Nasional. 1(1): $1-10$

Lingga, L. (2010) Cerdas Memilih Sayuran. Jakarta: PT AgroMedia Pustaka

Manuaba (2010) IImu Kebidanan Penyakit Kandungan dan KB. Jakarta: EGC

Merlina, A. (2016) Investasi Emas Hijau dari Budidaya Bayam. Depok: Vilam Media

Nursalam (2013) Metodologi Penelitian IImu Keperawatan: Pendekatan Praktis. Jakarta: Salemba Medika

Qolik, A. (2014) Buku Pintar Bertanam Bayam \& Sawi. Yogyakarta: Indoliterasi

Sivanganam, S. \& Weta, W. (2017) Gambaran tingkat kepatuhan ibu hamil mengkonsumsi tablet besi di wilayah kerja puskesmas Sidemen tahun 2015. Jurnal Intisari Sains Medis. 8(2): 135-138. DOI: 10.1556/ism. V8i2.128

WHO (2015) Worldwide prevalence of anemia 2013-2015. WHO global database on Anaemia Geneva: World Health Organization

Wijayanti, T. (2016) Perbaikan Status Hb (hemoglobin) pada Ibu Hamil Trimester Pertama dengan Jus Daun Bayam (Amaranthus Tricolor. L). Jurnal Edubiotik. 1(1): 30-34

Winarno F.G. (2004) Kimia Pangan dan Gizi. Jakarta: Gramedia Pustaka Utama

Yunaifi, S. (2013) Jurus Sempurna Sukses Bertanam Bayam. Jakarta Barat: PT. Maha Daya 